\title{
Too Many Meanings: Contestation of Lawang Sewu as a Heritage Tourism Attraction
}

\author{
Uswatun Nurul B \\ Universitas Gadjah Mada, Indonesia \\ Email: uswatun.nurul.b@mail.ugm.ac.id
}

\begin{abstract}
Tourism industry utilizes heritage as a tourist attraction. Not only the physical existences, but also the meaning of its heritage, particularly its narrations, are used to gain profit for tourism industry. Lawang Sewu located in Semarang, Indonesia is one heritage which is used by PT KeretaApi Indonesia (PT KAI) as a heritage tourism attraction. This research analyses many meanings or narrations of Lawang Sewu as a heritage tourism attraction. This research has three objectives. First, it aims to identify the meaning of BPCB Central Java, PT KAI, local people, tour guides and tourist interpretations of Lawang Sewu. Second, it aims to discover which stakeholder dominates the narrations presented in Lawang Sewu. Third, it seeks to understand how the dominant stakeholder can govern the narrations. This research is a qualitative research with inductive reasoning. Through the use of interactive analysis model as the data analysis method and hermeneutics approach to draw the conclusion, this research finds that each stakeholder construes the meaning of Lawang Sewu differently. Among the interpretations, PT KAI is the dominant stakeholder found in the presentation of Lawang Sewu to tourists.
\end{abstract}

Keywords: Heritage tourism attraction, interpretation dominance, Lawang Sewu.

\section{Background}

Tourism industry utilizes heritage as a cultural attraction. Heritage meanings are encoded into narrations and used as the capital for providing tourists with experience and knowledge. The narrations of the heritage can be diverse. This is because heritage is an epitome from the past in which the meanings are derived from continuous interpretation by various users over different contexts and interests (Sudarmadi, 2014: 21). Using Colonial building Lawang Sewu in Semarang, Central Java, Indonesia as an example of such discourse, this article discuss the way in which Lawang Sewu meanings are continuously enunciated in different contexts by many users from the time it was built in 1904 up to now. Further, this article deliniates Lawang Sewu heritage meanings from various stakeholders, and shows that its meaning, not only constructs in many times formation, but also from social, history, economic, and political context.

\section{Theoretical Basis}

Actually, heritage comes from the English word inheritance (Nuryanti, 1996: 249; Vecco, 2011: 321). Today, heritage is defined as particular representation that is continuously maintained through generations; they are symbols that provide a pathway to the past, through the present, and to the future, at a private or collective level (Kelly, 2009: 91). From this definition, we can conclude that Lawang Sewu is a heritage as it is a legacy handed down from the past. 
As a legacy, Lawang Sewu cannot be considered as a heritage building without acknowledging its meanings. In fact, Lawang Sewu is categorized as a heritage building not only due to its tangible features, but also due to its intangible features to provide historical existence, relationship, and meanings to the present society. Heritage meanings do not simply lie within heritage waiting to be discovered (as viewed from the constructionist approach of heritage, or the notion of heritage meanings being intrinsic), but is created by people (Mason, 2002: 8; Hall, 2007:25). Therefore, Lawang Sewu's heritage building narrations are constructed by its users.

In Lawang Sewu, the heritage users are the stakeholders involved in the conservation, utilization, and management of Lawang Sewu as a tourism attraction. It includes BPCB as the authorized stakeholder of heritage conservation in Indonesia, PT KAI as the official manager of Lawang Sewu, local people and tour guides as the stakeholders who utilize Lawang Sewu as a place to generate income, and tourists as the stakeholder who utilize the building as a place of recreation.

Different heritage users create diverse heritage meanings as people continuously encode it by presuming the heritage as readable narrations (Sudarmadi, 2014: 18- 21). In Lawang Sewu, the stakeholders also interpret the building diversely. The two distinctive interpretation of Lawang Sewu are first, during colonialism era. The building meaning was about an administrative office of the Dutch Railway company and remarks the development of Indonesian railway system in Java Island. Second, in the present time, the building becomes as a historical rail way museum, especially for tourist attraction, since, it possesses capital asset for tourism industry. This means that the building can be monetized by providing tourist gaze (Throsby, 1996: 6; Byrne et.al., 2001: 55).

Disparity of stakeholders' interpretation often leads to the dominance issues within the heritage building's narration. One stakeholder's might be more powerful than the others, therefore, their interpretation dominates the narrations presented to tourists. This is because the interpretation is often imbued by political agendas and intended to monopolize the heritage's management, creating a particular dominant power and authority in interpretation (Puckzó, 2006: 240; Ratz, 2005: 133; Wright \& Lennon, 2007: 520). In order to understand the dominance issue and how it influences the narrations construction, the work of interpreting heritage can be understood as the work of hermeneutics discourse. Interpreting Lawang Sewu heritage means to provide meanings, to represent or to construct meanings out of its existence through broadcasts narration and communicates it to receiver. Indeed, the hermeneutics goal itself is also to generate understanding for anyone seeks to obtain meanings. Hermeneutics itself is the philosophical underpinnings of any kind of interpretation, as well as what Odman (1988:63) argues that hermeneutics is the theory and practice of interpretation and understanding in different kinds of human contexts.

Furthermore, the central of hermeneutics understanding is the hermeneutic circle. It describes that in order to understand the heritage meanings, one need to consider the contexts where they are established (Shanks \& Tilley, 1992: 104). These are the 'contextual factors', the situations or factors that are always exist and affect the interpretation. In this research, the concept of recognizing the contextual factors will map out all interpretations of the Lawang Sewu narrations from the numbers of stakeholders views. More importantly, this research will reach out the stakeholders' contextual factors as well as their involvement in the stakeholders' dominance of interest.

\section{Research Methodology}

This research is a qualitative research using inductive approach. To collect the data, purposive sampling method was used to determine series of respondent who had significant impacts and interests in Lawang Sewu. These included the stakeholders' representatives of BPCB Central Java, PT KAIwhich played role in the conservation, utilization, and management of Lawang Sewu as a tourism attraction, local people, tour guides and tourists. For the method of data collection, depth interview, semi-structured interview, participant observation, as well as background context are used.

Further, data in this research were analyzed using interactive analysis model by Miles et.al (2013: 8-37). First, data went to the data 
condensation process where data were selected based on its relevance to the research questions. Transcriptions of interview recordings of the stakeholders' interpretations of Lawang Sewu, transcriptions of tour guides' narrations presented during the tour, captions of exhibits as well as the documentary video presented to tourists, and other documents were coded and clustered into categories of meanings. Second, data were displayed. In this process, data condensed were organized, compressed, and assembled based on the categories found. Third, after data were condensed and displayed, we can conclude what narrations dominated and which stakeholder dominated the narrations presented in Lawang Sewu.

In order to draw the conclusion the hermeneutics approach is considered as a basic for understanding the interpretation of Lawang Sewu within series of timeline and different contexts. This approach enabled the understanding on how the interpretations of Lawang Sewu by stakeholders were different from time to time upon different stakeholders as influenced by contextual factorssocial, economic, history, and politic- in the period of interpreting Lawang Sewu.

\section{Research Findings}

View from time line formation and different contexts, it is clear that stakeholders of Lawang Sewu heritage tend to create, invent, and produce different meaning of such heritage. No wonder, that Lawang Sewu heritage has a number of contested narrations as follow.

\subsection{Meanings of Lawang Sewu to BPCB Central Java}

BPCB recognized Lawang Sewu as a building which has historical, scientific, education, and cultural significances. This building is considered having particular historical significances because of three reasons. First, Lawang Sewu is an architectural masterpiece of first decade of $20^{\text {th }}$ century. Second, Lawang Sewu was used as the office of the first company which constructed the first railway in Indonesia, the NetherlandsIndischeSpoorwegMaatschappij (NIS). Third, Lawang Sewu was relics displaying the evidence of the struggle of Angkatan Muda KeretaApi
(AMKA), which took a role as the witness of maintaining the independence of Indonesia during the Five-day Battle in Semarang.

As a building with scientific significance, Lawang Sewu represents pre-eminent architectural works. Building A of Lawang Sewu is an excellent model of the utilization of a pre-reinforced concrete structure system. Building A and B also represent innovative application of adaptive technology and architecture. For this reason, Lawang Sewu becomes the status of a very grand marker of urban landscape as can be seen in each building's hallway and air conditioning system which is such an unprecedented one in Indonesia.

Lawang Sewu is considered to have profound educational significance due to the building which becomes an epitome of great construction regarding its high quality planning and implementation which are along with the excellent material selection and execution. Lawang Sewu's construction also showed meticulous calculations, as it includes careful considerations of aspects such as the weather and climate conditions. In addition, Lawang Sewu's also demonstrates a high selection process on building constructionn. Lastly, Lawang Sewu is claimed to possess educational meanings by BPCB for the building is able to be an object of studies (e.g. architectural study) by elaborating its thorough building construction.

Lawang Sewu, from BPCB's perspective, has three main reasons for its cultural significance. The first are the Lawang Sewu's high aesthetics value and the integration of both Javanese and European cultural elements applied on the building. The second is Lawang Sewu's position as a supreme icon of culture, with many of its structures are considered to be iconic symbols for the city. Third, Lawang Sewu becomes a splendid marker of cultural landscape and urban landscape.

\subsection{Meanings of Lawang Sewu to PT KAI}

Within historical-related interpretation, Lawang Sewu has three meanings for PT KAI. First, Lawang Sewu is interpreted by PT KAI as a heritage building which holds the power to represent the history of development of the railway system in Indonesia. The construction itself is considered as the origin for Indonesian railway history for the building was the Dutch office of first railway constructor 
in Indonesia. This also remarks the history for the railway industry in Indonesia which represent the initial identity of PT KAI.

Second, Lawang Sewu is interpreted as a milestone representing entire railway development in Indonesia in the Dutch colonialism era. This mean that the building is seen as an attribute of the first railway lane built in plantation-producing areas, remarkable railway lanes, andhistorical buildings built throughout regions in Indonesia.

Third, Lawang Sewu is interpreted by PT KAI as the depiction of the railway technology development used in Indonesia. Various series of locomotive based on its function within the period presented in the museum demonstrate the development of railway business since the Dutch period up to the present time. All of these historicalrelated interpretations by PT KAI are evident in museum's exhibits in Building A and B and documentary film.

Within the architectural-related interpretation, PT KAI construes Lawang Sewu as a heritage building with exceptional architectural work of its era. As explained in the museum, Lawang Sewu was built with excellent architectural design, not only considering the aesthetics but also its function. Other than that, PT KAI also construes Lawang Sewu as a building which was built using high quality material, and highly calculated techniques. This results in the conservation technique of the building which can only be carried out by using the same or similar techniques of the original construction, including the materials used, measurement, and execution.

Within political-related interpretation, PT KAI interprets Lawang Sewu as a tool to promote the company's identity as well as promoting the company's vision to conserve nation's heritage. This is evident in the arrangement of the museum and content of the narrations which were designed to promote the conservation of Lawang Sewu and other historical railway buildings in Indonesia.

In the economic-related interpretation, PT KAI construes Lawang Sewu as an object with monetary capital because it is able to generate income. Lawang Sewu is operated as a museum through providing recreational space for tourists. PT KAI also opened Lawang Sewu as a place for exhibition, seminar, meeting, pre wedding photo venue and wedding ceremony.

\subsection{Meanings of Lawang Sewu to Local People}

Within historical related interpretation, Lawang Sewu is interpreted to have three meanings by local people. First, they mentioned that the building is a historical remains from Dutch colonialism period, with age of more than hundred years old, and strongly related with the history of the Dutch in Indonesia. Second, local people interpret Lawang Sewu as a prison and a place of beheadings during Japanese occupancy:

"People in Semarang believe that Lawang Sewu is a historical building. Many people say that in Lawang Sewu, the underground level, there was the prison. The stand-up prison and squat prison used by Japanese to punish Indonesian people. That was the place for the prisons and as a place where massacres and beheadings took place"

Third, Lawang Sewu is deemed historically significant based on the local people's perspective because it is the place where Five-Day Battle in Semarang Occurred. Local people reveal that the trestle in Building A which was hit by mortar fire is an evidence of the historical event that happened during Japanese occupancy.

In a similar way, local people also construe Lawang Sewu within spiritual and mystical-related interpretation. First, local people expressed their beliefs that Lawang Sewu is a scary building looked haunted:

\section{"Lawang Sewu was so scaryat that time. The image was so scary. It was not maintained, the walls were peeled off. The bushes were so high that it reaches maybe half to one meter in height. From the outside, Lawang Sewu looked haunted. People were afraid to come inside."}

Local people added that in 2003, the underground level of Lawang Sewu was used as the shooting location of the famous horror TV show at that time, Dunia Lain. Moreover, in 2007, the building was also used as the shooting venue of an Indonesian horror movie entitled "Lawang Sewu -DendamKuntilanak".

It is no wonder, local people explained that 
there were many tourists who visited Lawang Sewu to look for spiritual experiences. They witness tourists looking for blessings, and even watch tourists become possessed after visiting Lawang Sewu. These emphasize local people's beliefs that the building is haunted.

Within social-related interpretation, local people construe Lawang Sewu as a reputable building in Semarang which is also the icon of Semarang. Local people connect Lawang Sewu as being part of the identity of Semarang. They are also proud of its international fame, shown by hot its tourists come not only from Indonesia but also from abroad.

In the economic-related interpretation, local people interpret Lawang Sewu as a place to earn a living. There are many local people that undergo economic activities within Lawang Sewu. Some of them work as managerial staff of PT KAI. Thirty five tour guides worked in Lawang Sewu are also local people who lived in Lawang Sewu surroundings. Other local people are the souvenir sellers, food and beverage sellers, caricature service provider, photo service provider and players in local band performed in Lawang Sewu.

\subsection{Meanings of Lawang Sewu to Tour Guides}

The tour guides of Lawang Sewu interpreted the building in relation to historical, architectural, social, and economic meanings. Within the historicalrelated interpretation, there are three meanings from both PT KAI and the tour guides which are quite similar. First, is the Lawang Sewu which represents the development of the railway system in Indonesia. Second, Lawang Sewu as the building representing Indonesian railway development. Third, Lawang Sewu as the building explaining about the railway technology used in Indonesia.

However, there are some additions of narrations highlighted by the tour guides. This distinction is concerning the situation of Lawang Sewu and its surroundings during Dutch colonization. Tour guides also explained about the brief history of Semarang which includes the story of construction of several historical buildings related to Lawang Sewu, and the origin of Lawang Sewu which was named as the building with thousand doors.

Further, tour guides interpreted Lawang
Sewu as the office of Japanese transportation agency, RikuyuSokyoku and its utilization during the era. Moreover, tour guides also mentioned that the underground level of Building B was used as an underground prison and a place of beheading, as well as once used as the shooting location of Dunia Lain TV show. This narration is still presented during guided tours up until now. However, the tour guides tell the tourists that the prison story has yet to be tested and that there is no evidence for it. During interview, one guide explained that the belief of the history is claimed to only be a myth:

"If it (Lawang Sewu) is mentioned as the place of slaughter, as the place of beheading, I do not think that it is true. Possibly this conception started due to people's nescience about the original story of Lawang Sewu, and then it was spread and believed by many people. At that moment, people loved to hear a controversial story. Well, if Lawang Sewu was utilized as a prison during the Japanese... maybe it was possible, considering how the Japanese was so vicious to our people".

In addition, tour guides also interpreted that during the Five-Day Battle in Semarang, the building became a historical place of battle between the Indonesians and Japanese.

For the architectural-related interpretation, tour guides construe Lawang Sewu as a building with unique architecture. In the interview, one of the tour guides mentioned that Lawang Sewu is a magnificent Dutch relic with architecture that cannot be found elsewhere in Indonesia. The tour guide also believe that the magnificent aesthetic of the building's architecture is also a part of tourists' motivation in visiting Lawang Sewu. The architecture of Lawang Sewu even astonished the tour guides. The tour guides never expect that the details of the building's construction would be such a wonder. These factual architectural information obtained from PT KAI were presented along with additional explanation from the tour guides' own architectural information such as interpretations about the reverse window and about the restroom which was located outside the main building.

Tour guides also construe Lawang Sewu 
in social-related interpretation. Lawang Sewu is interpreted as the icon of Semarang. The tour guides witnessed the transformation of a heritage building that became the symbolic building of their city. Thus, they perceive Lawang Sewu as an icon, a landmark of Semarang city and part of Semarang's identity.

In the economic-related interpretation, Lawang Sewu is interpreted to have two meanings. First, since the early operation of Lawang Sewu as a tourist attraction up to the present time, they construe the Lawang Sewu as a place entailed with economic value. Previously, they independently operated Lawang Sewu building, including opened up the underground level for tourists. In the early years of Lawang Sewu foreclosure, they lost their position as operators of the attraction so that they also lost their authority to utilize the underground level of Lawang Sewu. They deplored PT KAI's decision in closing the underground level as they argue that it was one of the tourist's most lucrative point of interest, hence it is the most beneficial one.

Second, through reviewing the activity performed by tour guides in Lawang Sewu, it can be concluded that they construe the building as a place for generating income. Although the building is officially managed by PT KAI, the tour guides are still allowed to work as freelance guides there as long as they have official guide license.

\subsection{Meanings of Lawang Sewu to Tourists}

Based on the interviews conducted with tourists, their interpretations of Lawang Sewu are historical, architectural, aesthetic, economic, mystical, and tourism related interpretation. These interpretations were acquired from both guided and non-guided tourist.

Some of tourists' interpretation is similar with the presented narrations of Lawang Sewu from PT KAI and the tour guides. First, tourists interpret the building as the administration office of the first railway constructor in Indonesia, the NIS. Second, tourists construe Lawang Sewu as the building representing the development of Indonesian railway. Third, they interpret the building as the prison during Japanese occupation. Fourth, they recognize Lawang Sewu as the place of the Battlefield of Five-Day Battle in Semarang. Fifth, tourists interpret Lawang Sewu as a historical remain of the Dutch colonialism period which allows them to acknowledge their past. Many visitors believe that Lawang Sewu should be protected so that the next generation will be able to witness the history and the struggle of Indonesia while one tourist from Suriname expressed that this relation triggered their memory on how the building was a reminder of his past:

"My grandparents were transferred by the Dutch using ships from TanjungEmas harbor, here in Semarang. For months they sailed in the ocean, promised that they will get decent work, hired by the Dutch. They arrived in Suriname, and now we live there. Visiting Lawang Sewu means visiting the place where I can remember my history, the history of the Javanese and Indonesians, in Suriname."

Tourists also explained the building within the architectural-related interpretation. First, they recognize the splendour of building's architecture specifically the thousand doors which is distinctive. Second, they also recognized Lawang Sewu as a typical masterpiece of Dutch architectural work:

"This is the Dutch typical construction. Not carelessly built. The blueprint and everything was taken into account, built specifically to meets its function. Not just a building but a sturdy one. The basement and the thousand doors, was purposed as an air conditioning system. It must have been built by the Dutch or else we cannot find this kind of building."

In a similar way tourist behold Lawang Sewu as a unique example of Dutch technique construction. Tourists added that by visiting Lawang Sewu, they could see the construction technique used which is no longer used at the moment. The building construction technique is something extraordinary since it was built without using cement. Lawang Sewu was also perceived as a Dutch colonization era wonder, which is still able to be witnessed in the $21^{\text {st }}$ century.

Within aesthetical-related interpretation, first, tourists value Lawang Sewu as a highly 
aesthetical building. The color combination of the building is beautiful, so are the ceramic floors which are matched with the color of the bricks. The doors of the building are also highly aesthetic, as a tourist described how the parallel doors which were arranged neatly are a pleasant sight to look at. Other than that,they added that one of the most aesthetic parts of the building is the stained glass in Building A.

\section{The way in which PT KAl dominates The Lawang Sewu}

PT KAI is the official manager of Lawang Sewu. Not only conducting its conservation and revitalization, PT KAI also operates Lawang Sewu as a tourist attraction. After foreclosing Lawang Sewu, PT KAI funded and revitalized this heritage building from 2008 - 2011. Since then, Lawang Sewu has been officially managed as a museum.

The revitalization of Lawang Sewu is not merely to preserve the nation's cultural heritage, but it is also aimed to reinstate its function, to be operated as a tourist attraction which allows the building meanings to positively impact a wider audience. This purpose is presented in the Heritage and Conservation unit's main task and function, which is to educate and provide information about Indonesian railways.

Related with the presented narrations, PT KAI managed Lawang Sewu by providing narrations, arranging exhibition and setting up the tourist flow regulation. Continuous maintenance is operated there in order to maintain the preservation. In this practice, Lawang Sewu hires professional staff.

The constructed narrations, the procured exhibits and its arrangements of the displays are designed in alignment with PT KAI's mission to enforce the company's identity, which also become the Indonesian railway's identity. Almost all of the collections there contain historical narrations of the Indonesian railway. By reviewing the building's revitalization, construction of narrations, procurement of exhibition, as well as reorganizing the management, PT KAI takes a big role in determining the dominant narrations presented in Lawang Sewu.

\subsection{Preserving and Conservating of Lawang Sewu Building}

The narrations presented by PT KAI are in line with BPCB's efforts in the building's conservations. The role of BPCB Central Java in Lawang Sewu includes its efforts in preservation and conservation. However, as PT KAI already has their own qualified unit called The Heritage and Conservation Unit, $\mathrm{BPCB}$ only monitors and evaluates the revitalization and utilization of Lawang Sewu by PT KAI.

Even though BPCB do not directly rule the presented narrations, BPCB has a significant influence in the utilization of the Lawang Sewu heritage building as a tourist attraction by PT KAI. BPCB mentions that there are no limitations set for utilizing the building, as long as it is in compliance with the conservation effort such as providing a means for Lawag Sewu as a place for education. In this sense, BPCB's positive appreciation of Lawang Sewu's utilization as a living museum implies their support for PT KAI and its narrations.

\subsection{The Exclusion of Local People Narrations}

There is an indirect involvement between the local people and the dominant narrations presented by PT KAI. At first, Lawang Sewu was used as a place of residence by the local people before it was foreclosed and revitalized. The local people were given severance payments to move from Lawang Sewu. This indicates that PT KAI evacuated and overruled the local people in order to revitalize the building for the company's interest.

PT KAI, however, still allows the local people to involve in Lawang Sewu's tourist attraction practices. They are free to open food stalls, provide parking services, and sell souvenirs in designed areas. By giving new regulation for local people, PT KAI diminishes the possibility of the further involvement of local people in Lawang Sewu day to day activities in side the building. Hence, it legitimates PT KAI's status as the dominant stakeholder which can create the one and only narrative of Lawang Sewu heritage.

\subsection{Reinventing Narration and Educating Local Guides Narrations}

Guides have a direct involvement in the construction of PT KAI as the dominant stakeholder. Previously, mystical meanings were highly presented, even 
it became the main commodity of the narrations delivered to tourist. Only when Lawang Sewu was revitalized by PT KAI, these narrations begin to fade. Those narrations were then replaced with new meanings along with actual information given by PT KAI. It is done because PT KAI believes that the previous narrations presented to tourists are lacking in educational information and discourage wider audiences to visit Lawang Sewu. In practice, PT KAI only presents educational information through adjusting the exhibits. Undeniably, it affects the narrations delivered by tour guides.

PT KAI also warns tour guides, so that they lessen narrations unrelated to the building's original history. Specifically, PT KAI also warns the tour guides not to deliver narrations about the underground level of Lawang Sewu which was used as a prison or as a place of beheadings, or any other similar narrations about the use of the building during the Japanese occupancy. This was because PT KAI considers that these narrations have no authentic proof which can be accounted for. Tour guides are also given a workshop by PT KAI, which seems to be useful to enhance their informational knowledge on the building. In this workshop, tour guides are also given a guide book which contains factual information about Lawang Sewu.

All of the efforts can be seen as an attempt to conform the PT KAI's dominant narration.

\section{Conclusion}

Lawang sewu Colonial building as a heritage tourism attractions is diversely interpreted by different stakeholders. As a result there are many meaning and contesting narration of this building. As time goes by, the meaning tend to obscures, changes, and sometimes is dominated by a new meaning.

This research has showed that heritage narrations are not static, but dynamic. The narrations might develop and change over time and context, as each stakeholder from different perspective interpretates based on their interest to achieve social, economic, and political purposes, such as benefiting from tourist attraction of Lawang Sewu heritage, power and authority to control management of this heritage.

\section{References}

Brommer, B., Sidharta, A., Budihardjo, E., Siswanto, A., Montens, A. B., Soewarno, S. S., \& Stevens, T. 1995. Semarang, Beeld van een stad. Nederland: Asia Major.

Byrne, D., Brayshaw, H. and Ireland, T. 2003. Social significance: a discussion paper. New South Wales: National Parks and Wildlife Service.

Gadamer, Hans Georg. 1996. Truth and Method (2 ${ }^{\text {nd }}$ rev. ed., Joel Weinshemer\& Donald Marshall, Trans.). New York: Continuum.

Hall, S. 1997. "The Work of Representation" in Stuart Hall (Ed.) Representation: Cultural representations and signifying practices Vol. 2. London: Sage Publications, pp. 13-74.

Hodder, Ian. 1998. "The past as passion and play Catalhoyuk as a site of conflict in the construction of multiple pasts" in Lynn Meskell (Ed.) Archaeology Under Fire: Nationalism, Politics and Heritage in the Eastern Mediterranean and Middle East. London: Routledge, pp. 124-139.

Kelly, Catherine. 2009. "Heritage" in Thrift, Nigel and Kitchin, Rob, (Eds.) The International Encyclopedia of Human Geography. London: Elsevier, pp. 91-97.

Kinsella, E. A. 2006. "Hermeneutics and and Critical Hermeneutics: Exploring Possibilities Within the Art of Interpretation" in Forum Qualitative Socialforschung/Forum: Qualitative Social Research Vol. 7. No. 3, pp. 13-20.

Klinkhamer \& Ouendag. 1916. "Het Administraiegebouw der Nederlandsch-Indische Spoorweg Maatschappij te Semarang”. Nederlands-Indie Oud en Nieuw vol 1, Issue 1. pp. 23-31.

Marshall, C., \& Rossman, G.B. 2014. Designing Qualitative Research. Sage Publications.

Mason, R. 2002. "Assessing Valuies in Conservation Planning: Methodoligical Issues and Choices" in Marta de la Torre (Ed.) Assessing the Values of Cultural Heritage. California: The Getty Conservation Institutem, pp.5-49.

Miles, M. B., Huberman, A. M., \& Saldana, J. 2013. Qualitative data analysis. Sage Publications.

Nuryanti, W. 1996. "Heritage and Postmodern Tourism". Annals of Tourism Research, 23(2), pp.249-260.

Odman, P.J. 1988. "Hermeneutics" in John P Keeves inEducational research methodology and measurement: An international handbook. New York: Pergamon Press, pp. 63-70.

Puczkó, L.A.S.Z.L.O. 2006. "Interpretation in cultural tourism" in Smith, M. \& Robinson, M (ed.) Cultural Tourism in a Changing World: Politics, 
Participation and (re) presentation. Bristol: Channel View Publications, pp.227-244.

Rátz, T. 2006. "Interpretation in the house of terror, Budapest" in Smith, M. \& Robinson, M (ed.) Cultural tourism in a changing world: Politics, participation and (re) presentation. Bristol: Channel View Publications, pp.244-56.

Shanks, M., \& Tilley, C. Y. 1992. Re-constructing archaeology: theory and practice. London: Routledge.

Sudarmadi, T. 2014. Between colonial legacies and grassroots movements: exploring cultural heritage practice in the Ngadha and Manggarai Region of Flores.Dissertation, Vrije Univeristy Amsterdam.

Throsby, D. 1999. Cultural capital. Journal of cultural economics, 23(1-2), pp.3-12.

Vecco, M. 2010. A definition of cultural heritage: From the tangible to the intangible. Journal of Cultural Heritage, 11(3), pp.321-332.

Wright, A.C. and Lennon, J.J. 2007. Selective interpretation and eclectic human heritage in Lithuania. Tourism Management, 28(2), pp.519529. 